\title{
NASTOLETNIE MACIERZYŃSTWO \\ - SZANSA CZY OGRANICZENIE? \\ DOŚWIADCZENIA MAŁOLETNICH MATEK Z GRUP DEFAWORYZOWANYCH
}

\begin{abstract}
Skowrońska-Pućka Agnieszka, Nastoletnie macierzyństwo - szansa czy ograniczenie? Doświadczenia małoletnich matek z grup defaworyzowanych [Teenage Motherhood - Opportunity or Restriction? Experience Minor Mothers from Disadvantaged Groups]. Studia Edukacyjne nr 42, 2016, Poznań 2016, pp. 217-232. Adam Mickiewicz University Press. ISSN 1233-6688. DOI: 10.14746/ se.2016.42.13

This article deals with the issues of early motherhood. Early parenting is a critical event in the life of teenage girls. Teens are mentally and socially immature and unprepared to fulfill the role of mother. Besides minor mothers usually come from poor families, are pupils in primary or secondary schools, do not work, do not have a steady income and own apartment, and in this case remain under the custody care and educational institution. The article is an attempt to answer the question, as teenagers from disadvantaged groups, pupil of childcare centers and describe the experience of motherhood. What is surprising, despite initial concerns and difficulties in retrospect evaluate them as a gift and a blessing, a source of valuable life experience and even a protective factor against the occurrence of other problems care and education.
\end{abstract}

Key words: adolescence, pregnancy, teenage mother, care and educational institution

\section{Ciąża w wieku nastoletnim jako krytyczne wydarzenie życiowe}

Dostępne weryfikacje empiryczne wskazują, iż optymalnym wiekiem kobiety dla prokreacji jest przedział 26-30 lat, natomiast w miarę korzystnym 21-25 rok życia. Najmniej korzystny, jak wskazują znawcy problematyki, jest 
wiek poniżej 20. roku życia, jak również okres powyżej 40. roku życia ${ }^{1}$. Obecnie stosunkowo niewielka liczba kobiet decyduje się na potomstwo przed ukończeniem 20. roku życia. W efekcie wydłużonego okresu edukacji, zwiększonych szans uzyskania dobrej, satysfakcjonującej pracy, a także dostępności nowoczesnej antykoncepcji obserwuje się tendencje do przesunięcia w czasie decyzji o urodzeniu pierwszego dziecka.

$\mathrm{Z}$ tego powodu, $\mathrm{w}$ wielu krajach, zjawisko ciąży u młodocianych jest rzadkie. Nawet w krajach, gdzie częstość ciąż u młodych matek utrzymuje się na wysokim poziomie, jest to postrzegane jako zjawisko wyjątkowe wobec faktu, że wiek urodzenia pierwszego dziecka w tych krajach jest obecnie istotnie wyższy².

Należy jednak zauważyć, że mimo stale rosnącej społecznej akceptacji modelu życia, w którym najpierw zdobywa się wykształcenie, kwalifikacje zawodowe, niezależność finansową i mieszkaniową, a odsuwa w czasie decyzję o założeniu rodziny, mamy do czynienia z coraz wyraźniejszym obniżeniem wieku inicjacji seksualnej i w konsekwencji bardzo wczesnymi lub nawet, jak podkreślają badacze tej problematyki, (przed)wczesnymi ciążami w przypadku bardzo młodych dziewcząt - nastolatek.

Ciążę w wieku nastoletnim można zaliczyć do wydarzeń krytycznych. Wydarzenie życiowe, aby zyskało status wydarzenia krytycznego, musi wyodrębnić się $\mathrm{w}$ toku codziennych zdarzeń, ponieważ wiąże się $\mathrm{z}$ ważnymi wartościami, jest znaczące emocjonalnie i dotyka kluczowej dla jednostek sfery funkcjonowania. Daje się ono umieścić w konkretnym czasie i przestrzeni. Krytyczne wydarzenia życiowe należą do tych znaczących „kamieni milowych", w istotny sposób wpływających na kształt życia ludzkiego³.

Kryzys nie jest sytuacją zwyczajną, lecz „zawiłą, trudną do zrozumienia, która opiera się prostym opisom przyczynowo-skutkowym"4. Istnieje wiele definicji kryzysu czy sytuacji kryzysowej. Caplan uważa, iż ludzie

znajdują się $\mathrm{w}$ stanie kryzysu, kiedy napotykają przeszkodę w osiąganiu ważnych celów życiowych - przeszkodę, która w tym czasie jest nie do pokonania za pomocą

1 U. Kempińska, Matżeństwa młodocianych. Ciąża, ślub i co dalej...? Toruń 2012, s. 70.

2 Tamże, s. 70-71.

${ }^{3}$ Por. H. Sęk, Wsparcie społeczne - sposoby definiowania, rodzaje i źródła wsparcia, [w:] Wsparcie społeczne, stres i zdrowie, red. H. Sęk, R. Cieślak, Warszawa 2004, s. 50; K. Kuryś, Urodzenie pierwszego dziecka jako wydarzenie krytyczne w życiu kobiet i mężczyzn, Kraków 2010, s. 33; A. Skowrońska-Zbierzchowska, Doświadczenia małoletnich rodziców. Aspekty socjopedagogiczne, Gdańsk 2010, s. 39; E. Stanisławiak, Psychologia kryzysu, [w:] Psychologia kryzysu i interwencji kryzysowej, red. J. Plak, Warszawa 2012, s. 7.

${ }^{4}$ L. Brammer, Konflikty stużące pomaganiu. Procesy i umiejętności, Warszawa 1985, s. 91. 
zwyczajowych metod rozwiązywania problemów. Powoduje to stan dezorganizacji i zamieszania, w którym podejmowane są liczne próby nieudanych rozwiązań ${ }^{5}$.

Z kolei Sugerman przez zdarzenie krytyczne rozumie wszystkie te wydarzenia, które występowały planowo, niespodziewanie lub losowo, a ich pojawienie się związane było z wystąpieniem silnego stresu' ${ }^{6}$. Jak zauważa Alicja Skowrońska-Zbierzchowska, zgodnie z tym ujęciem, ciążę małoletniej dziewczyny lub narodziny dziecka w wieku nastoletnim można uznać za niespodziewane wydarzenie krytyczne ${ }^{7}$.

W przypadku rodziców dorosłych narodziny dziecka można interpretować przez pryzmat kryzysu rozwojowego. To wydarzenie $\mathrm{w}$ ich życiu należy bowiem uznać za naturalny, kolejny etap, co zwiększa szansę na pozytywne rozwiązanie kryzysu, który staje się pomostem między kolejnymi fazami rozwoju. Warto jednak zaznaczyć, że narodziny dziecka w wieku nastoletnim mogą przyczynić się do wystąpienia kryzysu sytuacyjnego nieoczekiwanego, nierozwojowego. Taka sytuacja ma miejsce, jeśli wydarzenie to wystąpi $\mathrm{w}$ nieodpowiednim czasie $\mathrm{i}$ towarzyszyć mu będą niesprzyjające okoliczności ${ }^{8}$. Tak zdarzenie krytyczne definiuje Anna Brzezińska (określając je mianem wydarzeń życiowych) i dzieli na punktualne oraz niepunktualne. Używając terminologii wspomnianej autorki, (przed)wczesna ciąża należy do zdarzeń krytycznych niepunktualnych. Są to bowiem wydarzenia, które występują zbyt wcześnie z punktu widzenia biologicznego, społecznego, emocjonalnego rozwoju9.

Ciąża w wieku nastoletnim należy niewątpliwie do zdarzeń, które mogą zaburzać funkcjonowanie i prowadzić do załamania linii prawidłowego rozwoju człowieka. Dla młodych dziewcząt jest sytuacją nową, nagłą, zazwyczaj nieplanowaną, niewątpliwie trudną. Ciąża przez nastolatki może być odbierana jako zagrożenie (dla figury, urody, eliminacji z życia towarzyskiego). Zaistnienie ciąży $\mathrm{w}$ wieku nastoletnim może stanowić poważną przeszkodę $\mathrm{w}$ realizacji planów edukacyjnych, zawodowych i innych. Dlatego bez wątpienia możemy ją zaliczyć do wydarzeń krytycznych. Potwierdzeniem niech będzie jej wysoka, dwunasta, pozycja na liście zdarzeń ży-

${ }^{5}$ Caplan, 1961, s. 18 za: R.K James, B.E Gilliland, Strategie interwencji kryzysowej, przekł. A. Bidziński, Warszawa 2004, s. 25.

6 Por. L Sugerman, Life-span development. Concepts, theories and interventions, London - New York 1986, s. 141, 152.

7 Por. A. Skowrońska-Zbierzchowska, Doświadczenia matoletnich rodziców, s. 40.

8 Por. tamże, s. 39, 41.

${ }_{9}$ Por. A. Brzezińska, Wydarzenia punktualne i niepunktualne w okresie dzieciństwa i dorastania, Remedium, 2003, 12(130), s. 47-48. 
ciowych uporządkowanych według siły stresu im towarzyszących ${ }^{10}$. Należy również pamiętać, iż stan ciąży sprzyja występowaniu zmian przystosowawczych, szczególnie ze strony układu neurohormonalnego. Zmiany te często wywołują zakłócenia równowagi emocjonalnej, prowadząc do silnych, ambiwalentnych reakcji uczuciowych. $Z$ powodu tych zmian nawet normalnie przebiegająca, planowana ciąża jest sytuacją trudną, stresującą, wymagającą od kobiety umiejętności radzenia sobie z nowymi, intensywnymi emocjami ${ }^{11}$. Wspomniane zaburzenia ze strony układu neurohormonalnego mogą utrudniać małoletnim matkom radzenie sobie w nowej sytuacji. Należy zwrócić uwagę na tragizm sytuacji, w której się znalazły, stojąc przed olbrzymim wyzwaniem, na które nie są przygotowane. Warto pamiętać, że pod adresem nastoletnich dziewcząt kierowane są określone oczekiwania społeczne. Dotyczą one (powinny dotyczyć) zadań rozwojowych charakterystycznych dla adolescenta. Wiążą się raczej z nabywaniem kompetencji człowieka dorosłego. Tymczasem,

odkrycie przez dziewczynę faktu bycia w ciąży oznacza desynchronizację zegara społecznego z zegarem biologicznym i pojawienie się $\mathrm{w}$ ramach jednostkowych biografii wydarzeń niepunktualnych w stosunku do schematu rozwojowego i oczekiwań społecznych formułowanych dla poszczególnych etapów rozwojowych ${ }^{12}$.

\section{Nastoletnie matki z grup defaworyzowanych - współwystępowanie kryzysów normatywnych i nienormatywnych}

W Polsce każdego roku na świat przychodzi od 14-16 tysięcy dzieci powitych przez nastolatki ${ }^{13}$. Zdarzają się sytuacje, $\mathrm{w}$ których młode matki nie mogąc liczyć na pomoc rodziny albo uzyskując z ich strony niewystarczające wsparcie, zmuszone są realizować obowiązki macierzyńskie w warunkach instytucjonalnych - najczęściej w placówkach opiekuńczo-wychowawczych,

${ }_{10}$ Por. M. Adamczak, Krytyczne zdarzenia życiowe i radzenie sobie z nimi - wybrane zagadnienia, [w:] Elementy psychologii klinicznej, t. II, red. B. Waligóra, Poznań 1992.

${ }^{11}$ Por. B. Bartosz, Doświadczanie macierzyństwa. Analiza narracji autobiograficznych, Wrocław 2002, s. 50.

12 E. Włodarczyk, Nastoletnie macierzyństwo jako problem indywidualny $i$ społeczny, [w:] Kapitat społeczny. Kumulacja i redystrybucja, red. K. Marzec-Holka, H. Guza-Steinke (red.), Bydgoszcz 2009.

13 Por. P. Szukalski, Nastoletnie macierzyństwo we wspótczesnej Polsce, Polityka Społeczna, 2001, 1; Rocznik Demograficzny 2013, http://stat.gov.pl/obszary-tematyczne/rocznikistatystyczne/roczniki-statystyczne/rocznik-demograficzny-2014,3,8.html, [dostęp: 11.01.2015]. 
w których umieszczane są wraz z dziećmi na skutek dysfunkcjonalności rodzin pochodzenia. $W$ takich okolicznościach współwystępują aż trzy wyjątkowo silnie obciążające kryzysy, spowodowane zazwyczaj nieplanowaną ciążą, umieszczeniem w placówce opiekuńczo-wychowawczej (a tym samym odseparowaniem od rodziny biologicznej, rodzeństwa, rówieśników i związane z koniecznością nawiązania nowych relacji w nieznanym instytucjonalnym środowisku placówki opiekuńczo-wychowawczej i koniecznością odnalezienia się w nowej szkole) oraz kryzysem normatywnym, jakim jest sam okres adolescencji. Obecnie pozytywne rozwiązanie kryzysu tożsamości należy do zadań zdecydowanie trudniejszych niż jeszcze kilkadziesiąt lat temu. Jak zauważa Agnieszka Cybal-Michalska, ,jesteśmy świadkami przejścia od świata uporządkowanego do rzeczywistości różnorodnej, niepewnej wieloznacznej, w której fundamentalną zasadą staje się przeżywanie ambiwalencji", a radykalne przemiany społeczne prowadzą do permanentnej autokreacji. Wspomniana autorka podkreśla, iż „znalezienie odpowiedzi na pytania $>$ Kim jestem? $<,>$ Kim się staję? $<$ nabierają szczególnego znaczenia i okazują się coraz trudniejsze do sprecyzowania"14. Mimo że dylematy tożsamościowe należą do naturalnych zjawisk związanych z okresem adolescencji, nie ulega wątpliwości, że pozytywne rozwiązanie tego kryzysu jest zdecydowanie trudniejsze dla małoletniej matki. Takie rozwiązanie utrudnia niezdolność młodej dziewczyny do refleksyjnej interpretacji własnego życia oraz pojawiający się w sytuacji nieplanowanej ciąży brak poczucia kontynuacji, co nieuchronnie prowadzi do dylematów tożsamościowych. Konflikt tożsamości, jakiego wielokrotnie doświadczają młode matki spowodowany jest współwystępowaniem w podmiocie wielości definicji siebie, niespójnych wewnętrznie, a nawet pozostających ze sobą w sprzeczności (matka vs. nastolatka, rówieśnicze życie towarzyskie vs. obowiązki rodzicielskie itp.) ${ }^{15}$. Trudno w przypadku nastoletnich matek mówić o poczuciu stałości własnego "Ja"; wielokrotnie doświadczają one uczucia, że poprzez zajście w ciążę, czy urodzenie dziecka stały się kimś innym, a ich życie różni się diametralnie od tego "sprzed ciąży”. Istotnym wymiarem tożsamości staje się również poczucie odrębności własnego "Ja", które w przypadku małoletnich matek wielokrotnie przybiera skrajną postać - poczucia (negatywnej) odmienności, utrudniając zaspokojenie potrzeby afiliacji i przynależności, a tym samym zbudowanie tożsamości grupowej, społecznej czy kulturowej16. Powodem

14 Por. A. Cybal-Michalska, Tożsamość młodzieży w perspektywie globalnego świata. Studium socjopedagogiczne, Poznań 2006, s. 11-12 i 26.

15 Por. tamże, s. 100.

16 Por. tamże, s. 94. 
utrudniającym pozytywne rozwiązanie kryzysu tożsamości może być ponadto

trudna sytuacja rodzinna i powszechnie występujący wówczas brak poczucia bezpieczeństwa, miłości i przynależności (...) oraz wychowanie pozbawiające godności, szacunku dla siebie i możliwości kształtowania się postaw niezależności w okresie późniejszym ${ }^{17}$.

Pozytywne rozwiązanie kryzysu zostaje utrudnione poprzez powszechnie występującą $\mathrm{w}$ przypadku (przed)wczesnego macierzyństwa utratę możliwości korzystania z przywilejów młodości. Nastolatka nie ma czasu na typowe dla tego okresu rodzaje aktywności, co spowodowane jest nadmiarem obowiązków wynikających z pełnienia roli matki. Prowadzi to do niepowodzenia w osiągnięciu poczucia mocnej, satysfakcjonującej i trwałej tożsamości, powodując rozproszenie ról albo poczucie dezorientacji co do tego, czym lub kim się jest. Nastolatka zostaje pozbawiona możliwości „eksperymentowania" tak charakterystycznego dla tego etapu rozwojowego (moratorium), a zmuszona zostaje do odgrywania "na serio" roli matki z pełnym zaangażowaniem, zanim zdążyła wypróbować inne role życiowe $\mathrm{w}$ celu ukształtowania trwałych postaw i wartości. Jak zauważa Grażyna Mikołajczyk-Lerman, "wyrwanie tego okresu z życia młodych to niepowetowana strata w zdobywaniu doświadczeń" 18 .

Wszystko to sprawia, że nastoletnie dziewczęta narażone są na silne fizyczne i psychiczne zaburzenia o podłożu stresowym. Dodatkowym źródłem stresu jest często trudna sytuacja rodzinna, rówieśnicza, czy szkolna, co niewątpliwie wpływa na funkcjonowanie młodych matek i jakość sprawowanych przez nie zadań ${ }^{19}$.

\section{Nastoletnie macierzyństwo szansa czy ograniczenie - analiza literatury}

Należy wskazać, że przeżywanie biograficznych wydarzeń krytycznych może być niebezpieczne lub stanowić zagrożenie, szczególnie w sytuacji,

17 D. Kubacka-Jasiecka, W poszukiwaniu tożsamości - od agresji potencjalnej do destruktywności, Kraków 2001, s. 61.

17 G. Mikołajczyk-Lerman, Małoletnie rodzicielstwo jako problem psychospołeczny, Polityka Społeczna, 2007, 8, s. 56.

18 Tamże.

19 Por. M. Bidzan, Nastoletnie matki. Psychiczne aspekty ciąży, porodu i połogu, Kraków 2007, s. 79 . 
kiedy człowiek nie posiada odpowiednich zasobów, aby sobie z nimi poradzić lub robi to w stopniu niewystarczającym (czemu może sprzyjać dorastanie $\mathrm{w}$ dysfunkcjonalnym środowisku). Może też być czynnikiem stymulującym dalszy rozwój

kryzys może stać się również okazją, ponieważ związane z nim nierozerwalnie cierpienie i ból zmuszają człowieka do szukania wsparcia i pomocy oraz podejmowania nowych sposobów działania ${ }^{20}$.

Coraz częściej znawcy problematyki zwracają uwagę, iż w polskich publikacjach naukowych wczesne rodzicielstwo zwykło się traktować jako zjawisko z zakresu patologii społecznej. Badacze zaliczają płodność nastolatek do kategorii problemów społecznych „wymagających szczególnego potraktowania i zbadania, który nie może być kwestią marginalną życia społecznego"21. Wiktoria Wróblewska i inni badacze wskazują na konieczność naukowego przyjrzenia się urodzeniom wśród nastolatek, z uwagi na liczne implikuje oraz negatywne konsekwencje wynikające $z$ wczesnego macierzyństwa o charakterze zdrowotnym, społeczno-ekonomicznym, jak i demograficznym ${ }^{22}$. Z kolei Jan Kolbowski za następstwa małoletniego macierzyństwa uważa pojawienie się "nowego typu problemów społecznych", takich jak feminizacja ubóstwa, nadumieralność dzieci nastoletnich matek, częste maltretowanie dzieci przez młode matki, nadmierna emocjonalność dzieci nastolatek ${ }^{23}$. Mariola Bidzan sytuację małoletniej dziewczyny w ciąży określa mianem „ekstremalnej”24. Według wspomnianej autorki, nastoletnia ciąża stanowi „wydarzenie niezgodne z wiekiem rozwojowym, (...) stwarzające pewne zagrożenie $\mathrm{w}$ rozwiązywaniu konfliktów wiążących się $\mathrm{z}$ wiekiem i utrudnia zrealizowanie zadań rozwojowych"25. Wynika to z konieczności podejmowania ról niekorespondujących $\mathrm{z}$ możliwościami zarówno fizycznymi, jak i psychologicznymi oraz społecznymi adolescentów ${ }^{26}$. Zbigniew Izdebski, Krzysztof Wąż i Tomasz Niemiec nazywają nastoletnie ro-

${ }^{20}$ Por. R.K. James, B.E. Gilliland, Strategie interwencji kryzysowej, s. 26; H. Sęk, Wsparcie spoteczne - sposoby definiowania, s. 51.

21 P. Bunio-Mroczek, Nastoletnie rodzicielstwo w tódzkich enklawach biedy, 2015, s. 18, http://dspace.uni.lodz.pl:8080/xmlui/bitstream/handle/11089/12501/Bunio-

Mroczek\%20Paulina\%20praca\%20doktorska.pdf;sequence=12015, [dostęp: 5.01.2017].

22 Por W. Wróblewska, Nastoletnie matki w Polsce - studium demograficzne na podstawie badania "Analiza młodych matek" z 1988 r., Warszawa 1991.

${ }^{23}$ J. Kolbowski, Nieletnie matki w Polsce, Problemy Rodziny, 1988, 4(160), s. 27-31; P. BunioMroczek, Nastoletnie rodzicielstwo w tódzkich enklawach biedy, s. 18.

${ }^{24}$ M. Bidzan, Nastoletnie matki, s. 46.

25 Tamże, s. 25.

${ }^{26}$ Por. M. Bidzan, Nastoletnie rodzicielstwo. Perspektywa psychologiczna, Gdańsk 2013, s. 9. 
dzicielstwo "przedwczesnym”, a posiadających dzieci nastolatków „zbyt młodymi" rodzicami ${ }^{27}$.

W literaturze anglosaskiej można dostrzec dwa nurty odmiennie oceniające konsekwencje wczesnego rodzicielstwa. Pierwszy nurt badań, wcześniejszy, traktuje wczesne macierzyństwo, czy szerzej rodzicielstwo, jako istotny czynnik $\mathrm{w}$ procesie dziedziczenia biedy i wykluczenia społecznego, utrwalający nierówności społeczne. Drugi z nich, późniejszy, stanowi krytyczną odpowiedź na przypisywanie wczesnemu rodzicielstwu wyłącznie negatywnego znaczenia, nie tylko przez badających to zjawisko naukowców, ale również przez mass media ${ }^{28}$.

W ramach krytycznego nurtu badań nad nastoletnim rodzicielstwem wskazuje się na pozytywne konsekwencje nastoletniego rodzicielstwa dla nastoletnich rodziców i ich rodzin oraz dla społeczeństwa. Za pozytywne efekty wczesnego posiadania dziecka doświadczane przez samych nastoletnich rodziców i ich rodziny uważa się:

- przyrost kompetencji, umiejętności, poczucia sprawstwa, poczucia własnej wartości, wiary w siebie;

- doświadczenie pierwszego w życiu sukcesu (jakim jest urodzenie i wychowywanie dziecka);

- wyjście z uzależnień (lub przynajmniej rozpoczęcie terapii), odcięcie się od niekorzystnie oddziałującego środowiska rówieśniczego (zerwanie kontaktów towarzyskich z osobami prezentującymi zachowania ryzykowne);

- ponowne podjęcie i kontynuowanie edukacji, wzrost aspiracji, poszukiwanie możliwości podnoszenia kwalifikacji zawodowych, podjęcie pracy;

- poprawę relacji z członkami rodziny (przede wszystkim rodzicami, rodzeństwem, dziadkami);

- zdobycie poczucia sensu w życiu, dojrzałości, dorosłości, pozytywnej tożsamości ${ }^{29}$.

\section{Ciąża w wieku nastoletnim szansa czy ograniczenie - narracje małoletnich matek, wychowanek placówek opiekuńczo-wychowawczych}

Wyniki licznych weryfikacji naukowych oraz rezultaty prowadzonych przeze mnie badań empirycznych ${ }^{30}$ wskazują, iż niezależnie od wieku, doj-

27 Por. Z. Izdebski, T. Niemiec, K. Wąż, (Zbyt)młodzi rodzice, Warszawa 2011, s. 11.

28 Por. P. Bunio-Mroczek, Nastoletnie rodzicielstwo, s. 38.

${ }^{29}$ Music 1993; Duncan 2007 za: P. Bunio-Mroczek, Nastoletnie rodzicielstwo, s. 26-27. 
rzałości, punktualności, stopnia przygotowania, czy szerzej okoliczności doświadczenia związane z macierzyństwem stają się istotnym elementem biografii kobiet.

Dziewczęta biorące udział w prezentowanych tu jedynie fragmentarycznie weryfikacjach empirycznych wskazały, że macierzyństwo nadało ich życiu nowy, "lepszy” kierunek. Mimo że dla większości z nich wiadomość o ciąży była zaskoczeniem, któremu towarzyszył ogromny stres, szok i w większości przypadków niesprzyjające okoliczności, dziewczęta decydowały się podjąć zadania wynikające z macierzyństwa, a z perspektywy czasu opisują macierzyństwo w kategoriach szansy i daru, choć należy zaznaczyć, że nie zawsze umiały, jak same wskazywały, ową szansę należycie wykorzystać.

Prezentowane tu, jedynie w niewielkim wycinku, wyniki weryfikacji empirycznych wykazały, że nastolatki charakteryzowały się silną tendencją do idealizowania zarówno własnej przyszłości, jak i partnera (ojca dziecka).

[Asia] (...) wygladało to troszeczkę inaczej niż sobie wyobrażałam. Wydawało mi sie, że to łatwe... ale potem wiedziałam już, że nie jest to łatwe, nie no bardziej byłam nastawiona na coś takiego. Wiedziałam już po kilku dniach, że nie będzie lekko, że nie jest to takie piękne, jak to widać oczami. Było ciężej, no bo jednak czło-

30 Przedmiotem prezentowanych tu fragmentarycznie weryfikacji empirycznych, realizowanych w latach 2013-2014, uczyniłam doświadczenie (przed)wczesnego macierzyństwa, które wpisało się na stałe w biografie małoletnich dziewcząt, wychowanek placówek opiekuńczo-wychowawczych. Będąc w bezpośrednim kontakcie z dziewczętami, które doświadczyły (przed)wczesnego macierzyństwa, a także w związku ze specyfiką i charakterem przedmiotu badań oraz podjętych problemów badawczych oscylujących wokół realizowanego w warunkach instytucjonalnych "trudnego macierzyństwa", jak również ze względów metodologicznych oraz humanistycznych, dla celów realizacji badania wybrałam jakościowy sposób prowadzenia weryfikacji empirycznych. Strategia ta pozwala ukazać trudne do zmierzenia, subiektywne zjawiska i problemy, poznać doświadczenia konkretnych osób (małoletnich matek) w ich środowisku życia (placówka opiekuńczo-wychowawcza, rodzina pochodzenia). Metoda biograficzna pozwoliła na poznanie swoistego rodzaju trajektorii życia dziewcząt, których wspólnym doświadczeniem stało się (przed)wczesne macierzyństwo. Techniką, jaką zastosowałam $\mathrm{w}$ trakcie prowadzenia weryfikacji empirycznych był wywiad pogłębiony. Celem zastosowania wywiadu było uchwycenie genezy zjawiska, sekwencji zdarzeń prowadzących do zaistnienia (przed)wczesnego obowiązku macierzyńskiego, unikalności problemu i implikacji z nim związanych, procesu rozwoju i dojrzewania małoletnich matek, kształtowania się poglądów na temat macierzyństwa i obowiązków z niego wynikających. Badania umożliwiły wgląd w życie nowo powstałej rodziny, obarczonej dużym stresem, poczuciem niepewności i zagubienia. O doborze próby badawczej zadecydowały względy poznawcze. Dokonano wyboru celowego. W przypadku omawianych badań kryterium doboru były płeć (kobiety) oraz fakt zaistnienia ciąży lub urodzenia dziecka przed osiągnięciem pełnoletności, a także pobyt w placówce opiekuńczo-wychowawczej. 
wiek zmęczony, no nie ogarniałam tego wszystkiego, a jak jeszcze mnie jakiś wychowawca zdenerwowat, to w ogóle furii szło dostać...

[Angelika] Myślałam, że będzie łatwiej. A tu nie wszystko było takie łatwe, jak się wydawało. (...). Byłam zmęczona, bardzo zmęczona. Początki byty masakryczne.

[Ewa] Nie no, mi się zdawało, że będzie dobrze jak urodzę. On (ojciec dziecka) byt strasznie za mna. Myślatam, że z nim zamieszkam, jakaś prace, ale to nie było tak wszystko wcale lekko, fajnie jak mi się wydawało.

Idealizowanie swojej sytuacji to zjawisko szczególnie łatwe do zaobserwowania w przypadku dzieci i młodzieży przebywających w systemie opieki zastępczej. Mowa o tzw. „kompleksie Kopciuszka”

tj. zahamowania wewnętrzne, spaczone postawy, które są wynikiem utrudnień napotykanych w normalnym zaspokajaniu potrzeb kontaktu emocjonalnego. „Kompleks Kopciuszka" stanowi jedną z odmian kompleksu różnicy. Dziecko wie, że jest w gorszej sytuacji, ale jest przekonane, że pewnego dnia wszystko się zmieni ${ }^{31}$.

Badane dziewczęta, mimo że charakteryzowała je silna wiara w przyszłość związku, zmuszone były niejednokrotnie konfrontować wyidealizowane oczekiwania z bolesną rzeczywistością. Związek zazwyczaj rozpadał się, dzieci traciły kontakt $\mathrm{z}$ ojcami lub stawał się on coraz rzadszy, a negatywne konsekwencje związane $\mathrm{z}$ macierzyństwem ponosiły $\mathrm{w}$ znacznej mierze jedynie małoletnie wówczas dziewczęta i ich dzieci.

[Mirka] Ja wiedziałam, że moje życie nastolatki się skończyło...

[Daria] Ja widziałam, jak ta moja kuzynka, co też tak wcześnie miała (dziecko). Wiedziałam, że to będzie bardziej na zasadzie, że będę siedzieć $i$ nic nie będę mogła robić sama. Nie mogłam wychodzić z pokoju, bo dzieciaczek mały... Macierzyństwo było bardzo ograniczające, bo miałam obowiązki w placówce, a do tego jeszcze dziecko (...)

Okres ten (przynajmniej na początku) nie był wcale przyjemnym, jak to sobie wyobrażały, doświadczeniem. Mówiąc o (przed)wczesnym macierzyństwie wspominały o lęku i obawach, których stopień, jak wskazuje ana-

${ }^{31}$ M. Prokosz, Dziecko osamotnione i sieroce. Między rodzina pochodzenia a rodzinna forma opieki, [w:] Człowiek w sytuacji (bez)nadziei - konteksty teoretyczne i praktyczne, red. R. Babik, A. Urbaniak, Legnica 2011, s. 12. 
liza narracji, uzależniony był od udzielonego im wówczas wsparcia. A mimo to z perspektywy czasu macierzyństwo oceniają jako wartość i dar.

[Pola] No, było ciężko, ale tak właśnie miało być. Na dobre mi to wyszło.

Analiza narracji wskazuje, że

ciąża może być postrzegana - w skrajnych postaciach - w kategoriach ciężaru (fizycznego, finansowego, ruchowego, psychicznego; waga każdego z nich jest inna) i stanu błogosławionego - jako dwa krańce jednego wymiaru (choć naturalnie między nimi znajduje się wiele pośrednich stanów) ${ }^{32}$.

[Angelika] Myślę, że ta ciąża to byto coś dobrego. No wiadomo, że bycie $w$ ośrodku nie jest niczym dobrym, fajnym, no wiadomo jakieś ograniczenie jest, no ale też sporo uczy...

[Daria] Myślę o tej ciąży jako o szansie, odkąd trafitam do placówki zrobiłam się innym człowiekiem, inaczej się patrzy na świat... Dużo się nauczyłam... Z jednej strony jestem zła na mame, że musiatam tam trafić, bo to przez nią... ale $z$ drugiej strony dzięki temu, że ta ciąża ... dziecko... dużo się nauczyłam, obowiazków, rozporządzenia czasu, naukę łączyć z obowiązami i doroste decyzje podejmować.

Dzięki ciąży w wieku nastoletnim możliwe stało się panowanie nad pokusami życia młodzieżowego oraz kontynuowanie nauki.

[Pola] Ja wcześniej myślałam, że to było jakieś straszne ograniczenie dla mnie, ale teraz wiem, że jednak byta to jakaś szansa na... No bo jak bym byta tak naprawde $w$ domu, no to nie wiem, jakby to było... Co interesowatoby mnie bardziej? (Natalia czy znajomi). Znaczy bardziej Natalka... chyba... ona była upragnionym dzieckiem, ale jeszcze miałabym taki etap imprez, że miałabym, że mama zostanie czy babcia czy cokolwiek... A tak jednak musiałam i tak w to weszłam, że po prostu ciesze się, że tak się stato, a nie inaczej (...). Pozytywnie byłam nastawiona wtedy... Wiadomo wszystko ma plusy i minusy...

[Ola] Jak zaszłam $w$ ciażę to tam już chodzitam do szkoty normalnie. Już tam mówię, że dzięki temu chociaż se szkołę skończę. Bo wiedziałam, że jakbym nie poszła... to bym tej szkoły w ogóle nie skończyła. No to już było pewne $i$ wiedziałam na sto procent, nie? Uważam, że to była dla mnie szansa, że nawet z jednej strony

32 E. Włodarczyk, $O$ „rodzeniu się" macierzyństwa, [w:] Konteksty wspótczesnego macierzyństwa. Perspektywa młodych naukowców, red. J. Deręgowska, M. Majorczyk, Poznań 2012, s. 103. 
dobrze, że zaszłam (w ciąże), bo skończyłam sobie ta szkołę i tam trochę się nauczytam, ale też trochę tam przeżyłam niepotrzebnie...

Mimo początkowych problemów i obaw, większość biorących udział $\mathrm{w}$ prezentowanych weryfikacjach empirycznych kobiet, byłych wychowanek placówek opiekuńczo-wychowawczych uznała, że macierzyństwo, które zbiegło się z pobytem w placówce opiekuńczo-wychowawczej, było dla nich cennym źródłem życiowych doświadczeń. Sprawowanie matczynej opieki, oprócz oczywistych korzyści dla dziecka, wiązało się często z poczuciem zadowolenia i satysfakcji również u nastoletniej matki. Nowe doświadczenia wynikające z realizacji obowiązków macierzyńskich, czy szerzej rodzicielskich, sprzyjały odkrywaniu potencjału tkwiącego $\mathrm{w}$ młodych matkach. W następstwie sytuacji kryzysowych udało się dostrzec zwiększenie umiejętności rozwiązywania problemów i lepsze wykorzystanie potencjału rozwojowego. Można więc rozważać rolę krytycznych sytuacji w stymulowaniu aktywności życiowej33.

\section{(Nie)wykorzystana szansa?}

Większość weryfikacji empirycznych wskazuje, że

urodzenie dziecka w okresie adolescencji - bez znaczenia, czy matka jest mężatką, czy też nie - wiąże się z większą liczbą dzieci, niedużą różnicą wieku między nimi, skróconym okresem edukacji matki, gorszą karierą zawodową, niższymi dochodami i większym prawdopodobieństwem rozwodu. Takie zależności zauważono u nastolatek afroamerykańskich, latynoskich i anglosaskich, więc negatywne skutki dotyczą wszystkich, bez względu na pochodzenie etniczne ${ }^{34}$.

Wyniki te, jak wskazywałam wyżej, potwierdzają także badacze zajmujący się zjawiskiem (przed)wczesnego macierzyństwa w Polsce.

Warto jednak zasygnalizować, że nie musi to być tak jednoznacznie smutny obraz. Jak trafnie wskazuje Kamila Burbicka, „nie należy wskazywać jedynie negatywnych aspektów nastoletniego rodzicielstwa, gdyż każda sytuacja, nawet ta najtrudniejsza, ma także swoje dobre strony" ${ }^{\prime 2}$. Badania na grun-

33 Por. K. Wąż, Społeczno-kulturowy kontekst zjawiska (przed)wczesnego rodzicielstwa, [w:] Kultura mediów, ciało i tożsamość - konteksty socjalizacyjne, red. W. Jakubowski, S. Jaskulska, Kraków 2011.

${ }^{34}$ H. Bee, Psychologia rozwoju człowieka, Poznań 1998, s. 338.

$35 \mathrm{~K}$. Burbicka, Oddziaływania profilaktyczne i wychowawczo-opiekuńcze wobec ciężarnych nastolatek, [w:] Wspótczesne determinanty profilaktyki i resocjalizacji nieletnich, red. S. Bobas, Radom 2010, s. 307. 
cie amerykańskim wskazują, że ponad połowie dziewcząt, które zaszły w ciążę przed osiemnastym rokiem życia, udaje się ukończyć szkołę średnią ${ }^{36}$. A wiele tych, które borykały się z problemami ekonomicznymi $\mathrm{w}$ pierwszych latach dorosłości, potrafi je przezwyciężyć około trzydziestego lub czterdziestego roku życia, zwłaszcza gdy ukończyły przynajmniej szkołę średnią ${ }^{37}$. Na gruncie polskim zdecydowanie trudniej o takie uogólnienie, co jest uwarunkowane brakiem badań poświęconych pozytywom wynikającym z (przed)wczesnego podjęcia przez adolescenta roli matki czy ojca ${ }^{38}$.

Warto pamiętać, iż pomimo że wydaje się to niemożliwe, (przed)wczesne macierzyństwo, na co wskazują również prowadzone przeze mnie weryfikacje empiryczne,

nie zawsze jest zaskakującym wynikiem nieprzemyślanych kontaktów seksualnych. Czasem jest to także owoc wielkiej miłości, świadomy i konsekwentny wybór młodych ludzi. Jego największą zaletą jest przyspieszony kurs dojrzewania dla nastoletnich matek oraz ojców, gdyż wiadomo doskonale, iż odpowiedzialność związana $\mathrm{z}$ utrzymaniem i wychowaniem dzieci to bardzo wymagające zadanie ${ }^{39}$

nawet jeśli młodzi rodzice wspierani są przez rodziców czy pracowników placówki opiekuńczo-wychowawczej. Liczne obowiązki, które determinowane są przez zaistnienie (przed)wczesnej ciąży oraz zobowiązanie wynikające $z$ podjęcia się roli rodzica mogą sprawić, że młodzież zapomni o sobie i skoncentruje swoją uwagę oraz energię na nowym, całkowicie od nich zależnym, członku rodziny. Kamila Burbicka wskazuje, że wczesne rodzicielstwo to również

szansa na poprawienie własnej samooceny. Jeśli młodzi rodzice, szczególnie matki, spostrzegają, iż opieka nad dzieckiem przychodzi im łatwo, sprawnie, z satysfakcją i przyjemnością, mogą zacząć budować własny obraz na podstawie postrzegania siebie jako dobrego opiekuna ${ }^{40}$.

Może to mieć szczególne znaczenie dla tych wszystkich nastolatek,

które $\mathrm{w}$ domu rodzinnym $\mathrm{w}$ związku partnerskim czuły się niekochane i niepotrzebne, wczesne rodzicielstwo może być również wspaniałą rekompensatą tych deficytów, ponieważ nagle pojawia się mała, bezbronna istota, całkowicie zależna od swoich rodziców, potrzebująca ich, kochająca, rozpoznająca ich w tłumie ludzi, do nich pierwszych wyciągająca rączki $(. . .)^{41}$.

\footnotetext{
36 Por. H. Bee, Psychologia rozwoju człowieka, s. 338-339.

37 Tamże, s. 338-339.

38 Por. A. Skowrońska-Zbierzchowska, Doświadczenia małoletnich rodziców.

${ }^{39} \mathrm{~K}$. Burbicka, Oddziaływania profilaktyczne, s. 308.

40 Tamże.

${ }^{41}$ Tamże.
} 
(Przed)wczesne rodzicielstwo (czy macierzyństwo) może więc odegrać szczególną rolę w życiu (zbyt)młodych rodziców, wychowanków placówek opiekuńczo-wychowawczych, dla których charakterystyczna jest opisana wyżej sytuacja. Wszystko to może sprawić, iż nieplanowana ciąża, która wydawała się ogromną tragedią przekreślającą wszystkie plany na przyszłość, będzie w konsekwencji życiową lekcją oraz cennym źródłem życiowych doświadczeń, a w przyszłości charakteryzowana będzie w kategoriach błogosławieństwa lub daru².

$\mathrm{Z}$ uwagi na niezwykle trudną sytuację charakteryzowanej kategorii młodzieży, wielorakie implikacje o charakterze indywidualnym, szczególnie psychologiczne, pedagogiczne, zdrowotne oraz te o charakterze społecznym związane z (przed)wczesną ciążą, problem ten powinien stać się przedmiotem dogłębnej analizy. Mała wiedza na temat specyfiki funkcjonowania małoletnich matek przebywających w placówkach opiekuńczo-wychowawczych oraz etiologii i profilaktyki omawianego zjawiska powoduje, iż jest to grupa młodych ludzi, która boryka się z wieloma problemami. Rozpatrywanie krytycznych wydarzeń biograficznych z perspektywy indywidualnego rozwoju powinno zmienić sposób rozumienia interwencji kryzysowej. $\mathrm{Z}$ takiego punktu widzenia celowa wydaje się nie tylko prewencja zdarzeń krytycznych, co bardzo często nie jest po prostu możliwe, ile podwyższenie indywidualnych możliwości i kompetencji w rezultacie przeżywanego zdarzenia, co może odbywać się między innymi zaraz po umieszczeniu w placówce opiekuńczo-wychowawczej w trakcie procesu usamodzielniania wychowanków i stanowić istotny czynnik chroniący przed wystąpieniem kolejnych problemów opiekuńczo-wychowawczych (na co wskazywały w swoich narracjach kobiety biorące udział w prezentowanych tu weryfikacjach empirycznych).

\section{BIBLIOGRAFIA}

Adamczak M., Krytyczne zdarzenia życiowe i radzenie sobie z nimi - wybrane zagadnienia, [w:] Elementy psychologii klinicznej, t. II, red. B. Waligóra, Wydawnictwo Naukowe UAM, Poznań 1992.

Bartosz B., Doświadczanie macierzyństwa. Analiza narracji autobiograficznych, Wydawnictwo Uniwersytetu Wrocławskiego, Wrocław 2002.

Bee H., Psychologia rozwoju człowieka, Wydawnictwo Zysk i S-ka, Poznań 1998.

Bidzan M., Nastoletnie matki. Psychiczne aspekty ciąży, porodu i połogu, Oficyna Wydawnicza Impuls, Kraków 2007.

42 Por. tamże. 
Bidzan M., Nastoletnie rodzicielstwo. Perspektywa psychologiczna, Harmonia Universalis, Gdańsk 2013.

Brammer L., Konflikty stużące pomaganiu. Procesy i umiejętności, Studium Pomocy Psychologicznej PTP, Warszawa 1985.

Brzezińska A., Wydarzenia punktualne i niepunktualne w okresie dzieciństwa $i$ dorastania, Remedium, 2003, 12(130).

Bunio-Mroczek P., Nastoletnie rodzicielstwo $w$ tódzkich enklawach biedy, 2015, http://dspace.uni.lodz.pl:8080/xmlui/bitstream/handle/11089/12501/BunioMroczek\%20Paulina\%20praca\%20doktorska.pdf;sequence=12015, [dostęp: 5.01.2017].

Burbicka K., Oddziaływania profilaktyczne i wychowawczo-opiekuńcze wobec ciężarnych nastolatek, [w:] Wspótczesne determinanty profilaktyki i resocjalizacji nieletnich, red. S. Bobas, Wyższa Szkoła Handlowa, Radom 2010.

Cybal-Michalska A., Tożsamość młodzieży w perspektywie globalnego świata. Studium socjopedagogiczne, Wydawnictwo Naukowe UAM, Poznań 2006.

Duncan S., What is the problem with parents? And what is the problem with policy? Critical Social Policy, 2007, 27(3).

Izdebski Z., Niemiec T., Wąż K., (Zbyt)młodzi rodzice, Wydawnictwo TRIO, Warszawa 2011.

James R.K., Gilliland B.E., Strategie interwencji kryzysowej, przekł. A. Bidziński, Warszawa 2004.

Kempińska U., Małżeństwa młodocianych. Ciaż̇a, ślub i co dalej...? Wydawnictwo Edukacyjne Akapit, Torun 2012.

Kolbowski J., Nieletnie matki w Polsce, Problemy Rodziny, 1998, 4(160).

Kubacka-Jasiecka D., W poszukiwaniu tożsamości - od agresji potencjalnej do destruktywności, Wydawnictwo Uniwersytetu Jagiellońskiego, Kraków 2001.

Kuryś K., Urodzenie pierwszego dziecka jako wydarzenie krytyczne w życiu kobiet i mężczyzn, Oficyna Wydawnicza Impuls, Kraków 2010.

Mikołajczyk-Lerman G., Małoletnie rodzicielstwo jako problem psychospołeczny, Polityka Społeczna, 2007, 8.

Music J.S., Young, Poor and Pregnant. The Psychology of Teenage Motherhood, Yale University, Yale 1993.

Prokosz M., Dziecko osamotnione i sieroce. Między rodzina pochodzenia a rodzinna forma opieki, [w:] Człowiek w sytuacji (bez)nadziei - konteksty teoretyczne i praktyczne, red. R. Babik, A. Urbaniak, Wyższa Szkoła Zawodowa im. Witelona w Legnicy, Legnica 2011.

Rocznik Demograficzny 2013, http://stat.gov.pl/obszary-tematyczne/roczniki-statysty czne/roczniki-statystyczne/rocznik-demograficzny-2014,3,8.html, [dostęp: 11.01. 2015].

Szukalski P., Nastoletnie macierzyństwo we wspótczesnej Polsce, Polityka Społeczna, 2001, 1.

Sęk H., Wsparcie społeczne - sposoby definiowania, rodzaje i źródta wsparcia, [w:] Wsparcie społeczne, stres $i$ zdrowie, red. H. Sęk, R. Cieślak, Wydawnictwo Naukowe PWN, Warszawa 2004.

Skowrońska-Zbierzchowska A., Doświadczenia małoletnich rodziców. Aspekty socjopedagogiczne, Wydawnictwo Uniwersytetu Gdańskiego, Gdańsk 2010.

Stanisławiak E., Psychologia kryzysu, [w:] Psychologia kryzysu i interwencji kryzysowej, red. J. Plak, Kodruk, Wydawnictwo WSP TWP, Warszawa 2012.

Sugerman L., Life-span development. Concepts, theories and interventions, Methein, London New York 1986. 
Wąż K., Społeczno-kulturowy kontekst zjawiska (przed)wczesnego rodzicielstwa, [w:] Kultura mediów, ciało i tożsamość - konteksty socjalizacyjne, red. W. Jakubowski, S. Jaskulska, Oficyna Wydawnicza Impuls, Kraków 2011.

Włodarczyk E., Nastoletnie macierzyństwo jako problem indywidualny i społeczny, [w:] Kapitat społeczny. Kumulacja i redystrybucja, red. K. Marzec-Holka, H. Guza-Steinke, Wydawnictwo Uniwersytetu Kazimierza Wielkiego, Bydgoszcz 2009.

Włodarczyk E., $O$ „rodzeniu się" macierzyństwa, [w:] Konteksty wspótczesnego macierzyństwa. Perspektywa młodych naukowców, red. J. Deręgowska, M. Majorczyk, Wyższa Szkoła Nauk Humanistycznych i Dziennikarstwa, Poznań 2012.

Wróblewska W., Nastoletnie matki w Polsce - studium demograficzne na podstawie badania "Analiza młodych matek" z 1988 r., Szkoła Główna Handlowa - Oficyna Wydawnicza, Instytut Statystyki i Demografii, Warszawa 1991. 